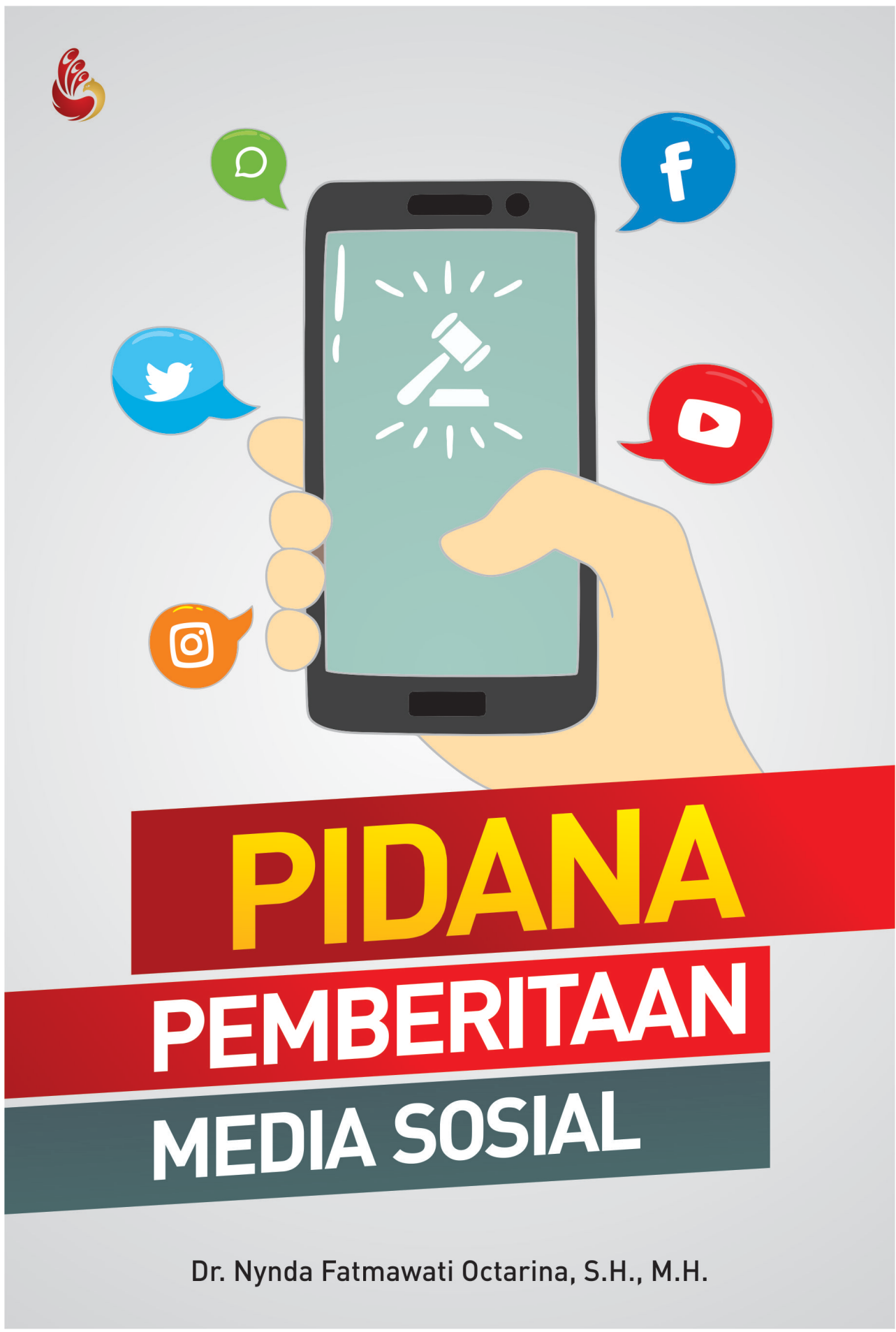




\section{PIDANA PEMBERITAAN \\ MEDIA SOSIAL}

Kebabasan Pers, Kode Etik Jurnalistik, dan Pertanggungjawaban Pidana

Dr. Nynda Fatmawati Octarina, SH.,MH. 


\section{DAFTAR ISI}

Sambutan Ketua Dewan Pers

Pengantar Penulis

Pengantar Penerbit

\section{Bab 1. Pendahuluan}

Bab 2. Pengaturan Perbuatan Jurnalis Yang Berimplikasi

Pidana

A. Pemberitaan oleh Jurnalis

1. Jurnalis

2. Teori Pers

3. Aspek Pidana Pemberitaan

B. Prinsip Kebebasan Pers

C. Media Sosial dan Prinsip Kebebasan dalam Penggunaannya

D. Kode Etik Jurnalistik sebagai Aturan bagi Jurnalis

Bab 3. Tanggungjawab Pers

Bab 4. Tindak Pidana dalam Pemberitaan

Bab 5. Pertanggungjawaban Pidana atas Pemberitaan dalam Media Sosial

Bab 6. Pertanggungjawaban Korporasi dalam Pemberitaan di Media Sosia

\section{Bab 7. Penutup}

Daftar Bacaan

Lampiran

1. Daftar putusan

2. Daftar perundang-undangan

Indeks

Tentang Penulis 


\section{Bab 1. PENDAHULUAN}

Pasal 28 Undang-Undang Dasar Negara Republik Indonesia Tahun 1945 (selanjutnya disebut UUDNRI 1945) menjamin kemerdekaan berserikat dan berkumpul, mengeluarkan pikiran dengan lisan dan tulisan. Pers yang meliputi media cetak, media elektronik dan media lainnya merupakan salah satu sarana untuk mengeluarkan pikiran dengan lisan dan tulisan tersebut. Fungsi maksimal itu diperlukan karena kemerdekaan pers adalah salah satu perwujudan kedaulatan rakyat dan merupakan unsur yang sangat penting dalam kehidupan bermasyarakat, berbangsa dan bernegara yang demokratis. Dalam kehidupan yang demokratis itu pertanggungjawaban kepada rakyat terjamin, sistem penyelenggaraan negara yang transparan berfungsi, serta keadilan dan kebenaran terwujud.

Pers yang memiliki kemerdekaan untuk mencari dan menyampaikan informasi juga sangat penting untuk mewujudkan Hak Asasi Manusia yang dijamin dengan Ketetapan Majelis Permusyawaratan Rakyat Republik Indonesia Nomor: XVII/MPR/1998 tentang Hak Asasi Manusia, antara lain yang menyatakan bahwa setiap orang berhak berkomunikasi dan memperoleh informasi sejalan dengan Piagam Perserikatan Bangsa-bangsa tentang Hak Asasi Manusia Pasal 19 yang dinyatakan: "Setiap orang berhak atas kebebasan mempunyai dan mengeluarkan pendapat; dalam hal ini termasuk kebebasan memiliki pendapat tanpa gangguan, dan untuk mencari, menerima, dan menyampaikan informasi dan buah pikiran melalui media apa saja dan dengan tidak memandang batas-batas wilayah".

Kemerdekaan pers merupakan salah satu wujud kedaulatan rakyat dan menjadi unsur yang sangat penting untuk menciptakan kehidupan bermasyarakat, berbangsa dan bernegara yang demokratis, sehingga kemerdekaan mengeluarkan pikiran dan pendapat sebagaimana tercantum dalam Pasal 28 UUDNRI 1945. Dalam kehidupan bermasyarakat, berbangsa, dan bernegara yang demokratis, kemerdekaan menyatakan pikiran dan pendapat sesuai dengan hati nurani dan hak memperoleh informasi, merupakan hak asasi manusia yang sangat hakiki, yang diperlukan untuk menegakkan keadilan dan kebenaran, memajukan kesejateraan umum, dan mencerdaskan kehidupan bangsa. Pers nasional sebagai wahana komunikasi massa, penyebar informasi, dan pembentuk opini harus dapat melaksanakan asas, fungsi, hak, kewajiban, dan 
peranannya dengan sebaik-baiknya berdasarkan kemerdekaan pers yang profesional, sehingga harus mendapat jaminan dan perlindungan hukum, serta bebas dari campur tangan dan paksaan dari manapun.

Reformasi di Indonesia mencakup reformasi hukum. Sebagai sebuah sistem, reformasi hukum akan meliputi :

1. Reformasi aturan hukum

2. Reformasi penegakan hukum

3. Reformasi pelayanan hukum

4. Reformasi profesi hukum

5. Reformasi pendidikan hukum

6. Reformasi sikap sosial terhadap hukum

Seiring dengan berkembangnya sejarah pers dunia, terdapat beberapa teori yang muncul terkait dengan kebebasan pers. Teori pers tertua adalah teori pers otoritarian yang lahir pada abad ke-15 sampai abad ke-16 disaat banyak negara di dunia menjalankan sistem pemerintahan otoriter, menyatakan bahwa pers harus mendukung kebijakan pemerintah dan mengabdi kepada negara, sehingga para penerbit diawasi melalui paten-paten, izin-izin terbit, dan sensor. Konsep ini menetapkan pola asli bagi sebagian besar sistem-sistem pers nasional dunia, dan masih bertahan sampai sekarang. Dalam hal ini negara memiliki kedudukan lebih tinggi daripada individu dalam skala nilai kehidupan sosial. Kepemilikan pers diperbolehkan baik secara privat atau publik. Teori ini menempatkan media massa dalam fungsinya menunjang negara dan pemerintah dengan kekuasaan untuk memajukan rakyat sebagai tujuan utama. Media massa berada sepenuhnya dalam pengawasan dan penguasaaan langsung oleh pemerintah negara tersebut.

Teori yang kemudian muncul adalah libertarian atau dikenal dengan teori liberal atau kebebasan. Teori ini disebut pula dengan teori pers bebas yaitu menilai bahwa manusia dipandang sebagai mahluk rasional yang dapat membedakan mana yang benar dan mana yang salah. Teori ini menyebutkan bahwa pers memiliki kebebasan yang seluas-luasnya untuk membantu manusia mencari dan menemukan kebenaran yang hakiki dan bukan sebagai alat pemerintah. Pers memiliki kebebasan tanpa batas. Pers dapat mengkritik dan berkomentar atas suatu pemberitaan atau isu. Setiap orang berhak mengungkapkan pendapat mereka melalui pers. Media atau pers dalam teori ini diawasi melalui pengadilan dengan syarat tidak diperbolehkan memuat pemberitaan yang berisikan penghinaan, kecabulan, dan kerendahan moral. Teori ini memiliki kelemahan yaitu media massa atau pers dapat dimiliki oleh pihak perorangan sehingga tidak menutup kemungkinan terjadinya monopoli. 
Dalam teori ini, pers disebut sebagai The Fourth Estate atau Pilar Kekuasaan Keempat setelah kekuasaan eksekutif, legislatif dan yudikatif sehingga pers harus bebas dari pengaruh dan kendali pemerintah. Pada teori ini, pers diberikan kebebasan tak terbatas. Pemilik perusahaan pers cenderung profit oriented sehingga pers kurang kontrol terhadap pemerintah dan kurang berminat terhadap kepentingan masyarakat. Teori ini tidak berhasil memahami masalah-masalah seperti proses kebebasan internal pers dan proses konsentrasi pers.

Teori yang hadir berikutnya adalah teori pers tanggung jawab sosial yang merupakan teori pengembangan dari teori pers libertarian. Teori ini berdasarkan pada asumsi bahwa prinsip-prinsip teori pers libertarian terlalu menyederhanakan persoalan. Teori ini bertujuan untuk mengatasi kontradiksi antara kebebasan media massa dan tanggung jawab sosialnya.

Teori pers yang terakhir adalah teori pers soviet komunis. Teori ini lahir 2 tahun setelah revolusi Oktober 1917 di Rusia dan berakar pada Authoritarian Theory yang pada akhirnya dianut 10 dari 11 negara yang dulu berada di bawah payung kekuasaan Uni Republik Sosialis Soviet. Pers di dalam teori ini menopang kehidupan sistem sosialis Soviet Rusia dan memelihara pengawasan yang dilakukan pemerintah terhadap segala macam kegiatan yang terjadi dalam kehidupan komunis. Sehingga di negara-negara penganut teori ini, hanya terdapat pers pemerintah tanpa adanya pers bebas dimana para pejabat pemerintah umumnya memutuskan dan menetapkan sendiri apa yang akan dituliskan oleh pers. Tetapi dengan bubarnya Uni Soviet, hanya Cina, satu-satunya negara, yang menganut sistem teori pers ini.

Perkembangan pers di Indonesia dibagi menjadi 2 (dua) periode, yaitu pers era kolonial dan pers era Negara Kesatuan Republik Indonesia. Tahun 1744, pada masa penjajahan Belanda, Indonesia telah memiliki surat kabar pertamanya bernama Bataviacshce Nouvelle di Jakarta. Kemudian pada tahun 1776, terbit surat kabar Venu Niews yang dikelola oleh orang-orang Belanda dan diterbitkan dalam bahasa Belanda sehingga hanya dimengerti oleh orang Belanda atau orang pribumi yang menguasai bahasa Belanda. Isi surat kabar ini merupakan bentuk perpanjangan tangan dari pemerintahan kolonial Belanda. Tahun 1854, diterbitkan majalah Bianglala dan tahun 1856 terbit Soerat Kabar Bahasa Melajoe di Surabaya yang keduanya ditujukan untuk orang pribumi. Pada abad ke-20, di Bandung diterbitkan surat kabar milik Indonesia bernama Medan Prijaji yang dikelola oleh Tirto Hadisurjo atau Raden Mas Djokomono yang dianggap sebagai pelopor dasar-dasar jurnalistik modern Indonesia.

Pers, sebagai subsistem komunikasi mempunyai posisi khusus dalam 
masyarakat Indonesia yaitu, menjadi jembatan komunikasi antara pemerintah dan masyarakat atau antar masyarakat itu sendiri. Sehingga pers memiliki fungsi sebagai pemberi informasi, alat pendidikan, sarana kontrol sosial, maupun sarana perjuangan bangsa untuk menumbuhkan kesadaran sosial. Kerjasama pers dengan pemerintah sendiri sudah dimulai semenjak masa perjuangan melawan penjajah. Pers dengan antusias mengobarkan semangat perjuangan untuk melawan penjajah. Kerjasama ini juga ditegaskan Presiden Soeharto pada tahun 1978 melalui pidato kenegaraan yang menyebutkan bahwa pers adalah salah satu partner pemerintah untuk bekerja.

Berbeda dengan negara komunis, pers di Indonesia bebas menyalurkan pendapat masyarakat walaupun kebebasan itu tidak mutlak, pers tetap dibatasi oleh peraturan-peraturan baik yang tertulis maupun tidak. Pers juga memiliki tanggung jawab untuk menimbang layak atau tidaknya suatu berita disiarkan. Sehingga sistem pers di Indonesia disebut pula dengan Pers Pancasila yang dirumuskan dalam Keputusan Sidang Pleno XXV Dewan Pers yang bersidang di Surakarta pada 1984, sebagai berikut:

1. Pers nasional adalah Pers Pancasila, dalam arti pers yang orientasi sikap dan tingkah lakunya berdasarkan nilai-nilai Pancasil dan UUD 1945.

2. Pers Pancasila adalah pers pembangunan, dalam arti mengamalkan Pancasila dan UUD 1945 dalam membangun berbagai aspek kehidupan bermasyarakat, berbangsa, dan bernegara, termasuk pembangunan pers itu sendiri.

Hakikat Pers Pancasila adalah pers yang sehat, yaitu pers yang bebas dan bertanggung jawab guna mengembangkan suasana saling percaya menuju masyarakat terbuka yang demokratis dengan mekanisme interaksi positif antara pers, pemerintah dan masyarakat.

Pemberitaan yang dilakukan oleh Pers mengikuti konsep penyampaian pesan dalam proses komunikasi, yang dalam pelaksanaanya menggunakan berbagai macam media yang ada. Menurut Kamus Besar Bahasa Indonesia, media dalam hal ini dapat diartikan sebagai:

1. Alat

2. Alat atau (sarana) komunikasi seperti majalah, radio, televisi, film, poster dan spanduk.

Media komunikasi adalah semua sarana yang dipergunakan untuk memproduksi, mereproduksi, mendistribusikan atau menyebarkan dan menyampaikan informasi. Media komunikasi sangat berperan dalam 
kehidupan masyarakat. Proses pengiriman informasi di zaman keemasan ini sangat canggih. Teknologi telekomunikasi paling dicari untuk menyampaikan atau mengirimkan informasi ataupun berita karena teknologi telekomunikasi semakin berkembang, semakin cepat, tepat, akurat, mudah, murah, efektif dan efisien. Berbagi informasi antar Benua dan Negara di belahan dunia manapun semakin mudah. Media massa dibagi menjadi dua bagian, media massa tradisonal dan media massa modern. Media massa tradisional memiliki otoritas kekuasaan terbitnya terbatas. Hal ini mengakibatkan informasi yang diterima baik dari sumber maupun dari penerima berita tidak memiliki keleluasaan sehingga besar kemungkinan untuk merekayasa informasi. Inilah kekurangan dari media massa tradisonal. Surat kabar, majalah, radio, televisi, dan film merupakan produk dari media massa tradisonal. Hingga saat ini media massa tradisional masih terus hadir dan berkembang di masyarakat. Seiring berkembangnya zaman, manusia melakukan berbagai perubahan dengan menciptakan dan mempopulerkan apa itu media massa modern.

Media massa modern memiliki ciri, yaitu sumber dapat mentransmisikan pesannya kepada banyak penerima (melalui SMS atau internet misalnya), isi pesan tidak hanya disediakan oleh lembaga atau organisasi namun juga oleh individual, tidak ada perantara, interaksi terjadi pada individu, komunikasi mengalir (berlangsung) ke dalam, dan penerima yang menentukan waktu interaksi. Dalam hal ini internet dan handphone termasuk ke dalam media massa modern. Perbedaan internet dibanding media komunikasi klasik dapat dilihat dari dua sisi, yaitu penggunaannya oleh komunikator dan komunikan serta sisi karakteristik internet sebagai media komunikasi. Perbedaan karakteristik internet dibanding dengan media klasik dalam sistem dan operasonal sebagai alat maupun medium komunikasi adalah sebagai berikut:

1. Perbedaan utama dan makro yaitu internet adalah media berbasis komputer

2. Internet sebagai media komunikasi memiliki penawaran interaktif yang dinamis terhadap penggunanya.

3. Media internet mampu menjadi pusat informasi dan sumber informasi yang tidak terbatas.

4. Luas jangkauan dari media internet tentu saja melintasi antar benua, antar negara, serta antar budaya.

5. Fungsi internet sebagai media, selain sama dengan fungsi media lain, media internet memiliki penawaran untuk pengembangan bidang jasa maupun bisnis sebagai bagian gaya hidup.

Internet memang menyediakan suatu ruangan bagi khalayak untuk berkspresi, baik lewat tulisan, video, gambar, suara, ataupun gabungan 
keempatnya namun tidak semua konten dalam internet memiliki nilai kepentingan untuk diketahui oleh khalayak. Banyak fasilitas lain dari internet yang jauh dari pengertian media massa itu sendiri, misalnya saja situs jejaring sosial yang sedang ramai dibicarakan saat ini walaupun tujuan utamanya bukan sebagai aplikasi dari komunikasi massa. Lewat media baru ini kini manusia sebagai pelaku komunikasi dapat lebih mudah berinteraksi dan menemukan berbagai jawaban dari pertanyaanpertanyaan dalam kehidupan sehari-hari.

Internet bukan hanya sekedar saluran komunikasi modern, namun juga merupakan rumah baru bagi kelompok-kelompok sosial yang tersegmentasi. Berbagai forum dan komunitas terbentuk dan berkembang melalui kehadiran internet. Hal ini menunjukan seberapa besar pengaruh internet dalam kehidupan manusia dewasa ini. Terminologi media sosial menunjuk pada berbagai macam hal yang menggunakan fasilitas internet dan layanan data yang mengijinkan pengguna untuk berpartisipasi dalam pertukaran online, berkonstribusi konten yang dibuatnya atau bergabung dengan komunitas online. Beberapa macam layanan internet mayoritas diasosiasikan dengan media sosial yang biasa kita kenal dengan web 2.0. Media sosial merupakan media yang terdiri dari berbagai macam seperti blog, wiki, social network, social bookmarking, layanan memperbaharui status seperti twitter, konten dunia maya dan juga laman untuk berbagi konten.

Pada akhir tahun 1990an, sebagai sebuah broadband internet menjadi semakin populer di masyarakat, website yang mengijinkan pengguna untuk menciptakan dan mengunggah konten mulai bermunculan. Media sosial pertama yang muncul yaitu pada tahun 1997 adalah sixdegrees.com. Semenjak 2002, semakin banyak website jejaring sosial yang bermunculan. Seperti friendster dan myspace. Pada akhir tahun 2000an, media sosial telah mendapatkan penerimaan tersendiri dan pelayanan yang ditawarkan jejaring sosial ini telah meningkatkan jumlah angka pengguna internet yang sangat besar. Pengguna facebook sudah berjumlah 1 triliun pengguna dari seluruh dunia pada November 2012 dan pengguna twitter telah mencapai 517 juta pengguna pada Juli 2012. Terdapat beberapa faktor yang menyebabkan pertumbuhan pengguna media sosial dengan cepat. Faktor-faktor ini termasuk di dalamnya faktor teknologi seperti peningkatan kemampuan broadband, peningkatan sarana atau alat atau software untuk mengakses internet, dan pengembangan kemampuan komputer dan handphone atau tablet. Selain itu, terdapat pula faktor sosial seperti penggunaan media sosial yang cepat berkembang di kalangan anak muda dan faktor ekonomi seperti semakin mudahnya jangkauan komputer dan software, dan pertumbuhan 
kepentingan reklame di website sosial media.

Media sosial memudahkan manusia untuk berinteraksi sosial. Media sosial telah menjadi cara baru untuk berkomunikasi, bekerjasama dan berdiskusi. Salah satu karakter konten atau unggahan penggunan internet ke jejaring sosial selain konten tersebut lebih mudah diakses oleh orang di seluruh dunia, tetapi juga yang lebih penting, media sosial dapat dipergunakan dimanapun dan kapanpun selama tersambung dengan jaringan data. Karena kemudahan itulah, apabila terdapat sebuah konten yang beredar di dunia maya, akan sangat sulit diketahui unggahan mana yang merupakan unggahan pertama dan alasan kenapa unggahan tersebut diunggah oleh pengguna.

Salah satu bentuk media sosial yang tersedia saat ini adalah Twitter. Twitter muncul pada tahun 2006 setelah kemunculan facebook. Twitter menjadi lebih populer dibandingkan facebook karena twitter merupakan sebuah mikro-blogging dan digunakan oleh sebagian besar selebriti. Pada awalnya penemu twitter mendefinisikan twitter sebagai sebuah pesan singkat yang berisikan informasi tidak penting dan sebuah celetukan dari burung. Oleh karena itu, rangkaian kata dalam status-update twitter disebut dengan tweet atau kicauan. Twitter memiliki hanya 140 karakter (huruf dan simbol) untuk setiap tweet-nya. Menurut Jack Dorsey, salah satu penemu twitter, hal ini dikarenakan batasan 160 karakter telah dipergunakan sebagai batasan dalam sms dan para penemu ingin setiap tweet memiliki sebuah nama pengguna (username).

Twitter sekarang tidak hanya dipergunakan untuk menginformasikan kepada temanmu mengenai harimu, tetapi juga telah merubah pola media, politik dan juga bisnis. Banyak informasi mengenai bencana alam, skor olahraga, kematian selebriti dan banyak lagi informasi publik yang dibagi melalui twitter. Twitter sebagai laman media sosial dan mikrobloging telah merubah komunikasi politik secara mendalam. Dahulu berita politik hanya disiarkan melalui grup yang diketahui atau dikenal oleh massa. Tetapi sekarang ini, kita melihat politikus dan masyarakat berbagi mengenai olokan politik dan opininya. Ini adalah era baru untuk citizen journalist dan kita melihat masyarakat dapat berbicara dan mengungkapkan pendapat mengenai hal-hal yang penting untuk mereka.

Indonesia, terutama Jakarta, merupakan kota yang paling aktif dalam mengunggah tweet di dunia. Indonesia juga termasuk ke dalam 5 besar negara-negara dengan jumlah pengguna twitter terbesar di dunia. Di Twitter, pengguna tak terdaftar hanya bisa membaca kicauan, sedangkan pengguna terdaftar bisa memosting kicauan melalui antarmuka situs web, pesan singkat (SMS), atau melalui berbagai aplikasi untuk perangkat seluler. Twitter dimiliki dan dioperasikan oleh Twitter, Inc., yang berbasis 
di San Francisco, dengan kantor dan server tambahan terdapat di New York City, Boston, dan San Antonio. Secara standar, kicauan (tweet) pengguna dapat terlihat oleh umum, namun pengguna dapat membatasi pengiriman kicauan hanya bagi pengikut mereka. Pengguna bisa berlangganan kicauan pengguna lain dengan cara mengikuti (follow) pengguna yang bersangkutan, dan pengguna yang mengikuti tersebut akan menjadi pengikut (followers) bagi pengguna yang diikutinya. Pesan di twitter dapat diakses oleh publik secara terbuka selain orang-orang yang mengikuti atau follower dari akun tersebut sehingga twitter adalah ruang publik dalam media internet dan penggunanya terikat dengan Undang-Undang Nomor 11 Tahun 2008 tentang Informasi dan Transaksi Elektronik (Lembaran Negara Republik Indonesia Tahun 2008 Nomor 58) (selanjutnya disebut UU ITE) yang telah dirubah dengan UndangUndang nomer 19 tahun 2016 tentnag Perubahan atas Undang-Undang nomer 11 tahun 20088 tentang Informasi dan Transaksi Elektronik. UU ITE juga mengatur tentang penghinaan sebagaimana yang diatur dalam KUHP. Penghinaan juga diatur dalam UU ITE Pasal 27 ayat (3) yaitu setiap orang dengan sengaja dan tanpa hak mendistribusikan dan/atau mentransmisikan dan/atau membuat dapat diaksesnya Informasi Elektronik dan/atau Dokumen Elektronik yang memiliki muatan penghinaan dan/atau pencemaran nama baik.

Saat ini Pasal 27 ayat (3) UU ITE tersebut menjadi perdebatan. Beberapa ahli menilai bahwa pasal tersebut digunakan sebagai lex specialis dengan ancaman yang lebih berat dari KUHP adalah tepat karena pengguna di media sosial membutuhkan perlindungan dan pertimbangan dampak kerusakan yang dihasilkan oleh pencemaran menggunakan teknologi informasi yang bersifat meluas, jangka panjang dan dapat berulang sehingga kerugian yang dialami korban jauh lebih besar (efek amplifikasi) dibandingkan apabila pencemaran terjadi melalui saluran konvensional. Ahli yang tidak sependapat dengan penerapan pasal ini dengan beragumentasi bahwa negara harus menjamin kebebasan berekspresi sebagai salah satu hak asasi manusia dan banyaknya pengguna media internet yang akan dapat dijerat dengan ancaman yang berat hanya karena menyatakan kritik atau ketidakpuasan atas apa yang dialaminya.

Kasus Prita Mulyasari melawan Rumah Sakit Omni Internasional digunakan sebagai salah satu dampak dan multi interpretasinya pasal ini. Diawali dengan ketidakpuasan atas layanan rumah sakit yang dituangkan dalam surat elektronik membuat pasien ditahan karena dianggap mencemarkan nama baik institusi rumah sakit. Awalnya Majelis PN Tangerang membebaskan Prita pada 2009, tetapi jaksa mengajukan upaya 
hukum kasasi dan dikabulkan MA. Atas dasar keputusan MA tersebut, oleh pihak Prita Mulyasari mengajukan Peninjauan Kembali (PK) atas perkara No. $22 \mathrm{PK} / \mathrm{Pid}$. sus/2011 dengan alasan diketemukannya novum (bukti baru) dan akhirnya oleh MA permohonan Peninjauan Kembali dikabulkan.Selain perkara pidana, gugatan perdata juga dilayangkan RS Omni Internasional. MA menolak gugatan perdata Omni tersebut pada 29 September 2010 yang diputus oleh Ketua MA yaitu Harifin A Tumpa. MA membatalkan putusan PN Tangerang dan Pengadilan Tinggi Banten yang mengabulkan gugatan Omni dan memerintahkan Prita membayar ganti rugi atas perbutan pencemaran baik yang dilakukannya.

Dalam kaitannya dengan kasus pencemaran nama baik, Mahkamah Agung telah mengeluarkan Surat Edaran Mahkamah Agung (SEMA) Nomor 13 Tahun 2008 tertanggal 30 Desember 2008 tentang Meminta Keterangan Ahli. SEMA tersebut ditujukan kepada seluruh Ketua Pengadilan Tinggi dan Ketua Pengadilan Negeri di Indonesia yang pada pokoknya menginstruksikan agar para hakim dalam menangani perkara yang berhubungan dengan pers meminta keterangan ahli dari Dewan Pers. Hal tersebut disebabkan karena mereka yang paling mengetahui seluk beluk pers secara teori maupun praktik.

Sebagai gambaran, Susi Pudjiastuti yang dipilih oleh Presiden Joko Widodo sebagai Menteri Kelautan dan Perikanan di Kabinet Kerja ramai diberitakan di media sosial karena tertangkap kamera sedang merokok di lingkungan istana negara. Dalam akun media sosialnya, Susi menyatakan telah meminta untuk tidak dimunculkan gambarnya pada saat merokok karena sedang tidak berada di dalam acara kenegaraan namun akhirnya foto itu tetap diunggah di media online, dan penyebarannya sangat cepat, salah satunya dilakukan oleh Fadjroel Rahman (@fadjroel), pemilik situs berita Pedoman News, dan disebarkan (retweet) oleh puluhan pengikutnya,walaupun menteri Susi tidak menuntut pemuatan gambarnya, namun dia merasakan imbas dari penyebaran gambarnya tersebut.

Perdebatan atas UU Pers sebagai lex specialis dari KUHP masih bergulir, salah satu argumen yang digunakan sebagai dasar adalah Pasal 50 KUHP dinyatakan bahwa, "barangsiapa melakukan perbuatan untuk melaksanakan ketentuan undang-undang tidak dipidana". Dalam Pasal 3 UU Pers dinyatakan bahwa fungsi pers nasional diantaranya sebagai media informasi dan kontrol sosial artinya selama dapat dibuktikan bahwa tulisan atau gambar yang dipublikasi adalah untuk informasi kepada masyarakat maka insan pers tidak dapat dipidana karena itu dibuat mekanisme sendiri untuk ditempuh yaitu melalui hak jawab dan hak koreksi. 
Hal ini dapat memunculkan perbedaan pendapat antara para hakim dalam satu putusan untuk satu kasus yang sama sebagaimana yang terjadi pada kasus pemimpin redaksi majalah Tempo Bambang Harimurti yang didakwa melakukan fitnah terhadap pengusaha Tommy Winata. Dalam putusan pengadilan tingkat pertama di Pengadilan Negeri Jakarta Pusat, Bambang Harimurti dihukum 1 (satu) tahun penjara karena melanggar ketentuan KUHP. Putusan ini dikuatkan oleh putusan Pengadilan Tinggi Jakarta tanggal 4 April 2005, namun Mahkamah Agung Republik Indonesia dalam putusannya tanggal 9 Februari 2006 membatalkan putusan pengadilan negeri dan pengadilan tinggi dan membebaskan Bambang Harimurti dari semua dakwaan dengan pertimbangan redaksi majalah Tempo sudah memberikan hak jawab kepada Tommy Winata, sesuai dengan ketentuan UU Pers. Sejauh ini tidak terdapat penjelasan dan pembatasan yang dimaksud peristiwa yang termasuk "informasi bagi masyarakat", selain dari pada itu dalam Pasal 310 angka (3) KUHP dinyatakan sebagai berikut:“ Tidak merupakan pencemaran atau pencemaran tertulis, jika perbuatan jelas dilakukan demi kepentingan umum"

Syarat publikasi yang berlaku bagi sebuah berita dapat memasukkan semua tulisan seorang wartawan kedalam kategori demi kepentingan umum. Penulis dalam penelitian ini akan menguji sejauh mana UU Pers mengatur pembatasan tersebut.

Wartawan tidak bisa dilepaskan dari perusahaan pers, artinya tulisan dari wartawan tersebut terpublikasikan di media dimana wartawan tersebut bekerja. Tulisan wartawan yang dipublikasikan oleh perusahaan pers tersebut ternyata menimbulkan kerugian kepada pihak ketiga maka perusahaan pers tersebut, tidak terkecuali pemimpin redaksi dapat dimintai tanggung jawab dan tanggung gugat atas timbulnya kerugian pada pihak ketiga.

Sebagaimana diuraikan penulis sebelumnya, berkembangnya teknologi informasi diikuti pula perkembangan media sosial. Beragamnya media sosial setiap orang dapat dengan mudah menyampaikan dan mengakses tentang berita atau opini. Wartawan, misalnya, dapat menyampaikan pula tentang berita atau opini di media masa di luar perusahaan pers dia bekerja. Berita atau opini dari wartawan yang termuat di media social tersebut dapat juga menimbulkan kerugian pada pihak ketiga. Persoalan tanggung jawab pidana dari wartawan atas tulisannya di media sosial yang merugikan pihak ketiga inilah yang menjadi fokus dalam penelitian ini, karena dalam peraturan perundangundangan yang berlaku normanya masih kabur (vage norm). 


\section{DAFTAR PUSTAKA}

\section{Buku/Literatur}

A. Sobur, Etika Pers Profesionalisme dengan Nurani, Humaniora Utama Press, Bandung, 2001

A.M. Dewabrata, Kalimat Jurnalistik: Panduan Mencermati Penulisan Berita, Kompas, Jakarta, 2004

Abdul Kadir Muhammad, Hukum Perjanjian, Alumni, Bandung, 1986 , Etika Profesi Hukum, Citra Aditya Bakti, Bandung, 2001

Alan B. Albarran, The Social Media Industries, Routledge, New York, 2013

Ali Moertopo, Strategi Pembangunan Nasional, CSIS, Jakarta, 1982

Andi Hamzah, BA Manalu, dan I Wajan Suandra, Delik-Delik Pers di Indonesia, Penerbit MSP, Jakarta, 1987

Andi Hamzah, Bunga Rampai Hukum Pidana dan Acara Pidana, Ghalia Indonesia, Jakarta, 1986]

Andi Zaenal Abidin. Hukum Pidana I, Sinar Grafika, Jakarta, 1983

Anonim, Ensiklopedi Politik Pembangunan Pancasila jilid 2, Yayasan Ciptaloka Caraka, Jakarta, 1984

Anshari Tayeb, Profesi Wartawan di Tengah Perubahan Watak Lembaga Penerbitan Pers, PUSHAM UBAYA, Surabaya, 1997

Asep Syamsul, Jurnalistik Praktis, Rosida, Bandung, 1999

Ashlee Humphreys, Social Media: Enduring Principles, Oxford University Press, New York, 2016

B. Mardjono Reksodiputro, Pertanggungjawaban Pidana Korporasi dalam Tindak Pidana Korporasi, FH UNDIP, Semarang, 1989

Bagir Manan, Menuju Pers Yang Bertanggung Jawab dan Sehat, Alumni, Bandung, 2010

Bambang Sadono, Penyelesaian Delik Pers Secara Politis, Pustaka Sinar Harapan, Jakarta, 1993 
Barda Nawawi Arief, Perbandingan Hukum Pidana, Rajawali Pers, Jakarta, 1990

Budi Suhariyanto, Tindak Pidana Teknologi Informasi (CYBERCRIME), PT. Raja Grafindo Persada, Jakarta, 2014

Cambridge International English Dictionary, Guide You to the Meaning, Cambridge University Press, 1995

Chaidir Ali dalam Arief Amrullah, Kejahatan Korporasi, Bayumedia Publishing, Malang, 2006

Chairul Huda, Dari 'Tiada Pidana Tanpa Kesalahan' Menuju Kepada 'Tiada Pertanggungjawaban Pidana Tanpa Kesalahan', Cetakan Pertama, Prenada Media, Jakarta, 2006

Christian Fuchs, Social Media: A Critical Introduction, British Library, 2014

Denis McQuail, Teori Komunikasi Massa, PT Erlangga, Jakarta, 2004

Departemen Pendidikan dan Kebudayaan, Kamus Besar Bahasa Indonesia, edisi kedua, Balai Pustaka, Jakarta, 1996

Departemen Pendidikan Nasional, Kamus Besar Bahasa Indonesia, Balai Pustaka, Jakarta, 2001

Didik Endro Purwoleksono, Hukum Pidana, Airlangga University Press, Surabaya, 2014

Djoko Prakoso, Asas-Asas Hukum Pidana di Indonesia, Liberty, Yogyakarta, 1987 , Perkembangan Delik Pers di Indonesia, Liberty, Yogyakarta, 1988

E. Suherman, Masalah Tanggung Jawab Pada Charter Pesawat Udara Dan Beberapa Masalah Lain Dalam Bidang Penerbangan (Kumpulan Karangan), Cet. II, Alumni, Bandung, 1979

E. Sumaryono, Etika Profesi Hukum: Norma-Norma Bagi Penegak Hukum, Kanisius, Yogyakarta, 1995

Edmon Makarim, Tanggung Jawab Hukum Penyelenggara Sistem Elektronik, Rajawali Pers, Jakarta, 2010

Effendy dan Onong Uchjana, Kamus Komunikasi, PT. Mandar Maju, Bandung, 1989 
Ermanto, Menjadi Wartawan Handal Dan Profesional, Cinta Pena. Yogyakarta, 2005

F. Andrew Wood and Matthew J Smitt, Online Communication, Lawrence Erlbaum Associates Publishers, London, 2005

F. Rachrnadi, Perbandingan Sistem Pers Analisis Deskriptif Sistem Pers di Berbagai Negara, Alumni, Bandung, 2005

Fikri Jufri, Beberapa Lama Lagi Pers Harus Tiarap?, ISEI - PUSHAM Ubaya, Surabaya, 1987

Fred S. Siebert, Empat Teori Pers, Intermasa, Jakarta, 1986

Fred S. Siebert, Theodore Peterson dan Wilbur Schramm, Four Theory of The Press, University of Illinois Press, 1956

H.Setiyono, Kejahatan Korporasi, Bayumedia, Malang, 2003

Hans Kelsen, General Theory Of Law and State, Russell \& Russel, New York, 1961

Harkristuti Harkrisnowo, Tindak Pidana dalam Perspektif Kitab Undang-Undang Hukum Pidana, dalam Pidana Islam di Indonesia, Peluang Prospek dan Tantangan, Pustaka Firdaus, Jakarta, 2001

Hasan Alwi, Kamus Besar Bahasa Indonesia, Ed. Ke-3, Balai Pustaka, Jakarta, 2002

Herlambang Perdana Wiratraman, Press Freedom, Law and Politics in Indonesia: Socio-Legal Study, Universiteit Leiden, Netherland, 2014

Hikmat Kusumaningrat dan Purnama Kusumaningrat, Jurnalistik Teori dan Praktek, PT. Remaja Rosda Karya, Bandung, 2005

I Robert Berkman, and Christopher A. Shumway, Digital Dilema: Ethical Issues for Online Media Proffesionals, Iowa State Press, 2003

J.C.T. Simorangkir, Hukum dan Kebebasan Pers, Percetakan Offset Angkasa, Bandung, 1979

Jacob Oetama, Perspektif Pers Indonesia, LP3ES, Jakarta, 1987

Jalaluddin Rakhmat, (ed), Komunikasi Internasional, PT Remaja Rosdakarya, Bandung, 1993 
Jimly Asshiddiqie, Ali Safa'at, Teori Hans Kelsen Tentang Hukum, Konstitusi Press, Jakarta, 2006

Julian Harris, Stanley Johnson, Kelly Leiter, Complete Reporter, 4th eds., MacMillan Publishing Company, London, 1981

K. Bertens, Etika, PT. Gramedia Pustaka Utama, Jakarta, 2007

Kansil, Pokok-Pokok Hukum Pidana, Pradnya Paramita, Jakarta, 2004

Leden Marpaung, Tindak Pidana Kehormatan, Raja Grafindo Persada, Jakarta, 1997

M.A. Moegni Djojodirdjo, Perbuatan Melawan Hukum, Pradnya Paramita, Jakarta, 1982

Mahmud Mulyadi dan Surbakti Feri Antono, Politik Hukum Pidana Terhadap Kejahatan Korporasi, PT Sofmedia, Jakarta, 2010

Masyhur Efendi, Dimensi/Dinamika Hak Asasi Manusia Dalam Hukum Nasional dan Internasional, Ghalia Indonesia, Jakarta, 1994

Menteri Hukum dan Hak Asasi Manusia, Undang-Undang R.I. Tentang Pornografi dan Informasi dan Data Transaksi Elektronik, Pustaka Mahardika, Yogyakarta, 2011

Michael Dewing, Social Media: An Introduction, Library of Parliament, Canada, 2012

Michel Walrave, Koen Ponnet, Ellen Vanderhoven, Jacques Haes, dan Barbara Segaert, Youth 2.0: Social Media and Adolescene, Springer, Belgium, 2016

Moeljatno, Asas-asas Hukum Pidana, Cetakan Kedua, Bina Aksara, Jakarta, 1984 , Azaz-Azaz Hukum Pidana, Bina Aksara, Jakarta, 1987

, Perbuatan Pidana dan Pertanggungjawab dalam Hukum Pidana, Seksi Kepidanaan Fakultas Hukum Universitas Gadjah Mada, Yogyakarta, 2000 , Asas-Asas Hukum Pidana, Rineka Cipta, Jakarta, 2002 , Asas-Asas Hukum Pidana, Edisi Revisi, Rineka Cipta, Jakarta, 2015

Muhammad Mufid, Etika dan Filsafat Komunikasi, Kencana Prenada Media Group, Jakarta, 2010 
Muladi dan Priyatno Dwidja, Pertanggungjawaban Korporasi dalam Hukum Pidana, Sekolah Tinggi Hukum Bandung, Bandung, 1991 , Pertanggungjawaban Pidana Korporasi, Kencana, Jakarta, 2010

Niniek Suparni, Cyber Space Problematika \& Antisipasi Pengaturannya, Sinar Grafika, Jakarta, 2009

Padmo Wahyono (ed), Masalah Ketatanegaraan Indonesia Dewasa Ini, Ghalia Indonesia, Jakarta, 1994

Peter Mahmud Marzuki, Penelitian Hukum, Kencana, Jakarta, 2005 , Penelitian Hukum (edisi revisi), Kencana, Jakarta, 2015

Philip Babcock Gove, Webster's Third New International Dictionary of the English Language, Merriem-Webster, 1993

Philip Kotler dan Kevin Lane Keller, Marketing Management, 14th Edition, Pearson, United States of America, 2012

Prasetyo Teguh, Hukum Pidana, Raja Grafindo Persada, Jakarta, 2011

R. Kriyantono, Etika dan Filsafat Ilmu Komunikasi, Universitas Brawijaya Press, Malang, 2012

R. Rachmadi, Perbandingan Sistem Pers, Gramedia, Jakarta, 1990

R.Soesilo, Kitab Undang-Undang Hukum Pidana (KUHP) Serta KomentarKomentarnya Lengkap Pasal Demi Pasal, Politeia, Bogor, 1995

Ramdlon Naning, Cita dan Citra Hak Asasi Manusia, PSHTN Ui, Jakarta, 1983

Ridqi Sjarief Assegaf, Pers Diadili, dalam Jurnal Kajian Putusan Pengadilan, ed. ke-3, LEIP3, 2004

Roeslan Saleh, Perbuatan Pidana dan Pertanggungjawaban Pidana Dua Pengertian Dasar dalam Hukum Pidana, Cetakan Ketiga, Aksara Baru, Jakarta 1983

Rudi Prasetyo dalam Dwidja Priyatno, Kebijakan Legislasi tentang Pertanggungjawaban Pidana Korporasi di Indonesia, CV. Utomo, Bandung, 2004 
S.R. Sianturi, Asas-Asas Hukum Pidana Indonesia dan Penerapannya, Alumni, Jakarta, 1996

Sam Abede Pareno, Manajemen Berita: Antara Idealisme dan Realita, Paygurs, Surabaya, 2006

Samsul Wahidin, Hukum Pers, Pustaka Pelajar, Banjarmasin,2005

Setiyono, Kejahatan Korporasi, Analisis Viktimologis, dan Pertanggungjawaban Korporasi dalam Hukum Pidana Indonesia, Averroes Press, Jakarta, 2002 , Kejahatan Korporasi, Bayumedia Publishing, Malang, 2005

Shidarta, Hukum Perlindungan Konsumen Indonesia (Edisi Revisi), Gramedia Widiasarana Indonesia, Jakarta, 2006

Soerjono Soekanto, Sosiologi Suatu Pengantar, CV. Rajawali, Jakarta, 1982

Soetan. K. Malikoel Adil dalam Muladi dan Dwidja Priyatno, Pertanggungjawaban Korporasi Dalam Hukum Pidana, STHB, Bandung, 1991

Stuart Allan, Online News. Two Penn Plaza, New York, 2006

Subekti, Pokok-Pokok Hukum Perdata, Intermasa, Jakarta, 1989

Sutamijah Hadi, Tentang Delik-Delik Pers, Jawa Timur Press, Surabaya,1960

Sutan Remi Sjahdeini, Pertanggungjawaban Pidana Korporasi, PT. Grafiti Pers, Jakarta, 2006

Sutarto, Encyclopedia Administrasi, MCMLXXVII, Jakarta

Suwoto Mulyosurdarmo, Peralihan Kekuasaan: Kajian Teoritis dan Yuridis Terhadap Pidato Newaksara, Gramedia, Jakarta, 1997

Tjipta Lesmana, Pers Indonesia dalam Teori dan Praktik, Pustaka Sinar Harapan, Jakarta, 1986

Totok Djuroto, Manajemen Penerbitan Pers, Remaja Rosdakarya, Bandung, 2000

William L. Rivers, Jay W. Jensen, Theodore Peterson, Media Massa \& Masyarakat Modern, Fajar Interpratama Offset, Jakarta, 2004

Wina Armada Sukardi, Keutamaan di Balik Kontroversi Undang-Undang Pers, Cet. Pertama,Dewan Pers, Jakarta, 2007 
, Cara Mudah Memahami Kode Etik Jurnalistik dan Dewan Pers, Dewan Pers, Jakarta, 2008

Winarni, Komunikasi Massa Suatu Pengantar, UMM Press, Malang, 2003

WJS Poerwadarminta, Kamus Umum Bahasa Indonesia, Penerbit Nasional Balai Pustaka, Jakarta, 1980

Zaim Uchrowi, Pemberdayaan Wartawan, ISEI - PUSHAM Ubaya, Surabaya, 1987

\section{Peraturan Perundang-undangan}

Kitab Undang-Undang Hukum Pidana (KUHP)

Kitab Undang-Undang Hukum Perdata (KUHPer) (Staatsblad Nomor 23 Tahun 1948)

Undang-Undang Nomor 1 Tahun 1946 tentang Peraturan Hukum Pidana

Undang-Undang Republik Indonesia Nomor 73 Tahun 1958 Menyatakan Berlakunya Undang-Undang Nomer 1 Tahun 1946 Republik Indonesia tentang Peraturan Hukum Pidana Untuk Seluruh Wilayah Republik Indonesia dan Mengubah Undang-Undang Hukum Pidana (Lembaran Negara Nomer 127 tahun 1958, Tambahan Lembaran Negara Nomer 1660 Tahun 1958)

Undang-Undang Nomor 11 Tahun 1966 tentang Ketentuan-Ketentuan Pokok Pers (Lembaran Negara Republik Indonesia Tahun 1966 Nomer 40, Tambahan Lembaran Negara 2812)

Undang-Undang Nomor 1 Tahun 1974 Tentang Perkawinan (Lembaran Negara Republik Indonesia Tahun 1974 Nomer 1, Tambahan Lembaran Negara Nomor 3019)

Undang-Undang Nomor 3 Tahun 1997 Tentang Pengadilan Anak (Lembaran Negara Republik Indonesia Tahun 1997 Nomor 3,Tambahan Lembaran Negara Republik Indonesia Nomor 3668)

Undang-Undang Nomor 39 Tahun 1999 tentang Hak Asasi Manusia (Lembaran Negara Republik Indonesia Tahun 1999 Nomor 165, Tambahan Lembaran Negara Republik Indonesia nomor 3886) 
Undang-Undang Nomor 40 Tahun 1999 tentang Pers (Lembaran Negara Republik Indonesia Tahun 2002 Nomor 139, Tambahan Lembaran Negara Republik Indonesia Nomor 3887)

Undang-Undang Nomor 20 Tahun 2001 tentang Perubahan Atas Undang-Undang Nomer 31 tahun 1999 Tentang Pemberantasan Tindak Pidana Korupsi (Lembaran Negara Republik Indonesia Tahun 2001 Nomor 134, Tambahan Lembaran Negara Republik Indonesia Nomor 4150)

Undang-Undang Nomor 23 Tahun 2002 Tentang Perlindungan Anak (Lembaran Negara Republik Indonesia Tahun 2002 nomor 109)

Undang-Undang Nomor 32 Tahun 2002 tentang Penyiaran (Lembaran Negara Republik Indonesia Tahun 2002 Nomor 139, Tambahan Lembaran Negara Republik Indonesia Nomer 4252)

Undang-Undang Nomor 11 Tahun 2008 tentang Informasi dan Transaksi Eletronik (Lembaran Negara Republik Indonesia Tahun 2008 Nomor 58, Tambahan Lembaran Negara Republik Indonesia Nomor 4843)

Undang-Undang Nomor 14 Tahun 2008 tentang Keterbukaan Informasi Publik (Lembaran Negara Republik Indonesia Tahun 2008 Nomor 61,Tambahan Lembaran Negara Republik Indonesia Nomor 4846)

Undang-Undang Nomor 44 Tahun 2008 tentang Pornografi (Lembaran Negara Republik Indonesia Tahun 2008 Nomor 181, Tambahan Lembaran Negara Republik Indonesia Nomor 4928)

Undang-Undang Nomor 32 Tahun 2009 tentang Perlindungan dan Pengelolaan Lingkungan Hidup (Lembaran Negara Republik Indonesia Tahun 2009 Nomor 140, Tambahan Lembaran Negara Republik Indonesia Nomor 5059)

\section{Jurnal/Makalah/Media Massa}

Albertus Magnus Sunur, Pertanggungjawaban Korporasi Sebagai Pelaku Tindak Pidana, dalam Jurnal Cendekia, Vol. 1, No. 2, Oktober 2012, UKDC, Surabaya

Andreas M. Kaplan, Users of The World, Unite! The Challenges and Opportunities of Social Media, Business Horizons v. 53 (1), 2010

Asnawi Murani, Aspek Hukum dan Tanggung Jawab Pers, dalam Jurnal Ilmu Komunikasi Vol. 2 No. 1 Juni 2005, Atmajaya Press, Yogyakarta, 2005 
Bagir Manan, Makalah Peranan Pendidikan Tinggi Hukum Dalam Reformasi Hukum, Dalam Majalah Hukum Varia Peradilan, 2007 , Menuju Pers yang Bertanggung Jawab dan Sehat, 2010 , Menuju Pers Yang Bertanggung Jawab dan Sehat, dalam Majalah Hukum Varia Peradilan, Tahun XXVI No. 299 Oktober 2010, Ikatan Hakim Indonesia (IKAHI), Jakarta, 2010

, Pers dan Hakim, dalam Majalah Hukum Varia Peradilan, tahun XXV No. 297 Agustus 2010, Ikatan Hakim Indonesia (IKAHI), Jakarta, 2010

, Pers, Praduga Tak Bersalah, dan Hak Atas Informasi, dalam Majalah Hukum Varia Peradilan, tahun XXVI No. 303 Februari 2011, Ikatan Hakim Indonesia (IKAHI), Jakarta, 2011

Buletin Tempo, ed. 14 Juni 2009

Dan Gilmor, Winter. "Where Citizens and Journalists Intersect". Nieman Report, Vol 59. No 4, 2005

Henderi dan Muhamad Yusuf, Design dan Implementasi Data Warehouse Sebagai Pengukur Kinerja, CCIT Journal, 2007

Iwan Awaluddin Yusuf, Bermasalah dengan Media, Bagaimana Menyelesaikannya?, dalam Harian Kedaulatan Rakyat, 2 April 2007

J.D. Lasica, "What is Participatory Journalism?" 2003-08-07, Online Journalism Review, August 7, 2003

Johan Galtung and Mari Holmboe Ruge, The Structure of Foreign News, dalam Journal of Peace Research Vol. 2 No. 1, Sage Publications, 1965

John Hiler, "Blogosphere: The Emerging Media Ecosystem", Nieman Report, Vol 59. No 4, 2005

Kasus "Suara Independen": Jaksa Tetap Menuntut Terdakwa Empat Tahun Penjara, Harian Kompas, 5 April 1997

Masmiar Mangiang, Mempertahankan Integritas Wartawan di Tengah Budaya Amplop

Mike Ward, Journalism Online, Oxford, Focal Press, 2002

Moch. Kurniawan, Jurnalisme Warga di Indonesia dan Tantangannya. Jakarta, 2007 
Richard Sambrook, "Citizen Journalism and the BBC", Nieman Report, Vol 59. No 4, 2005

Samsul Wahidin, Wahana Hukum Kritik dan Hak Untuk Berbeda Pendapat, Harian Surya, Jakarta, 23 Maret 1998

Secara Carmen G dan Brinzea Victoria M, Social Media, The $21^{\text {st }}$ Century Tool at the Service of Recruiting Talent, Economic Series, Issue 3, 2014

Shayne Bowman and Chris Willis, "We Media: How Audiences are Shaping the Future of News and Information." The Media Center at the American Press Institute, 2003

Simeon Edosomwan, dkk, The History of Social Media and its Impact on Business, dalam The Journal of Applied Management and Entrepreneurship, Vol. 16, No. 3, Minot State University Press, United States, 2011

T. Mulya Lubis, Realitas Hak Untuk Mendapatkan Informasi dan Berkomunikasi di Indonesia, Majalah Hukum dan Pembangunan No. 4 Tahun XVI 1986

Trisha Dowerah B, Effectiveness Of Social Media As A Tool Of Communication And Its Potential For Technology Enabled Connections: A Micro-Level Study, International Journal of Scientific and Research Publications, Vol. 2, Issue 5, 2012

\section{Internet}

45 Kasus Tindak Kekerasa Menghantui Misi Wartawan: Refleksi Hari Kebebasan Pers Internasional, 2012, diunduh dari http://www.rmol.co/read/2012/05/06/62897/45-Kasus-Tindak-KekerasanMenghantui-Misi-Wartawan-, pada 26 Juli 2015

Agar Mudah Mengelola Akun Twitter dan Membuat Kultwit, Download Template Excel Ini, 2013, diunduh dari http:/www.gugussakti.com/2013/06/agarmudah-mengelola-akun-twitter.html, pada 11 Februari 2014

Ali Sodikin, Delik Pers Dalam Sejarah Jurnalistik, http://angintimur147.blogspot.com 2009, diunduh pada 29 Desember 2014

Anonim, Komik Strip: Kultwit (Kuliah Twitter), 2010, diunduh dari http://tekno.kompas.com/read/2011/03/07/13215649/komik.strip.kultwit.k uliah.twitter, pada 23 Maret 2011 
ASh, Akhirnya, MA Bebaskan Prita Mulyasari, 2012, diunduh dari http://www.hukumonline.com/berita/baca/lt5057d8e58f799/akhirnya--mabebaskan-prita-mulyasari, pada 24 Desember 2014

Bahri Kurniawan, Kasus Misbakhun,Kubu Benny Handoko Kecewa Atas Keputusan Hakim, 2014, diunduh dari http://www.tribunnews.com/nasional/2014/02/05/kasus-misbakhun-kububenny-handoko-kecewa-atas-keputusan-hakim, pada 20 Februari 2015

Catherine-Mette Mork, Using Twitter in EFL Education, Jaltcalljournal, Vol. 5, No. 3, 2009, h. 41-56, diunduh dari http://journal.jaltcall.org/articles/5_3_Mork.pdf, pada tanggal 23 Juni 2016

D.S.Shiffman, Twitter As A Tool For Conservation Education And Outreach: What Scientific Conferences Can Do To Promote Live-Tweeting, Journal Of Environmental Studies And Sciences, Springer, 2012, diunduh dari http://sharkresearch.rsmas.miami.edu/assets/ pdfs/pubs/Shiffman\%202012\%20conference\%20live-tweeting.pdf , pada tanggal 23 Juni 2016

Effendi, Mukhtar, Peranan Internet Sebagai Media Komunikasi, dalam Komunika, Vol. 4 No. 1 Januari - Juni 2010, Purwokerto, 2010, diunduh dari http://download.portalgaruda.org/ article.php?article=49246\&val=3911, pada 10 November 2016

Felix Iwan Wijayanto, Social Media: Definisi, Fungsi, Karakteristik, diakses dari https://prezi.com/vddmcub_-ss_/social-media-definisi-fungsikarakteristik/, 17 April 2015

http://english.ohmynews.com/articleview/article_view.asp?no=385169\&rel_no=1

http://lpmprojustitia.blogspot.com/2010/05/pers-dan-jurnalistik.html

http://sejarahkita.blogspot.com/sejarah_pers

http://www.americanbar.org/, Free speech and social media: Where to draw the line, diunduh dari http:/www.americanbar.org/publications/youraba/2015/march-2015/abapanelists-debate-free-speech-limits-on-social-media.html, pada tanggal 23 Juni 2016

http://www.camerairaq.com/citizen_journalism

http://www.persdanjurnalistik.com/sejarahpersdiindonesia 
Isjet, Kronologi Kasus Prita Mulyasari, 2009, diunduh dari http://www.kompasiana.com/iskandarjet/kronologi-kasus-pritamulyasari_54fd5ee9a33311021750fb34, pada 25 Desember 2013

J.Ng., Jurnalis Malaysia Tuntut Kebebasan Pers, 2011, diunduh dari http://indo.wsj.com/posts/2014/01/06/jurnalis-malaysia-tuntut-kebebasanpers/, pada 10 Februari 2014

Lex Specialiskah Undang-Undang Pers dari KUHP?, diunduh dari http://www.hukumonline.com/detail.asp?id=10947\&cl=Fokus, pada 29 Oktober 2004

Lucy Budd, @doesyourairlinetweet? An empirical examination of the use of twitter by 50 international airlines, Journal of Airline and Management, Vol. 2, No. 2, h. 124-135, diunduh dari https://upcommons.upc.edu/bitstream/handle/2099/12920/37.pdf?sequence $=1 \&$ isAllowed=y, pada 23 Juni 2016

Mark Johnson, The History of Twitter, 2013, dalam http://www.socialnomics.net/ 2013/01/23/the-history-of-twitter/, diakses pada 17 Maret 2015

Marko Müller/Christa Saloh-Foerster, Kebebasan Pers Masih Terancam, 2012, diunduh dari http://www.dw.com/id/kebebasan-pers-masih-terancam/a15917937, pada 12 Januari 2015

Muladi (Guru Besar Hukum Pidana Emeritus Universitas Diponegoro), Pertanggungjawaban Pidana Korporasi, 2013, diunduh dari http://www.antikorupsi.org/id/content/pertanggungjawaban-pidanakorporasi, pada 6 Oktober 2015

Nicholas Andrei E. S. 2011. Koran Kuning, Etika dan Jurnalistik. http://komunikasimu.blogspot.com/2011/04/koran-kuning-etika-danjurnalistik.html. Diakses 4 Januari 2017

Panji Semirang. 2007. Kode Etik Jurnalistik. http://panjisemirang.multiply.com/journal/item/6/Kode-Etik-Jurnalistik?\&show_interstitial $=1 \& \mathrm{u}=\% 2 \mathrm{Fjournal} \% 2 \mathrm{Fitem}$. Diakses 4 Januari 2017

Perkembangan Hukum Pers di Indonesia, diunduh dari http://www.library.upnvj. ac.id/pdf/2s1hukum/205711019/bab2.pdf, pada 10 September 2013

Rachmawati Salahuddin, Perkembangan Media Print Memasuki Era Digital, 2015, diunduh melalui http://komunikasi.us/index.php/course/2720perkembangan-media-print-memasuki-era-digital, pada 05 Juni 2015 
Reportes Without Borders, Press Freedom Index 2013, diunduh dari http://en.rsf.org/press-freedom-index-2013,1054.html, pada 10 Maret 2014

RM, 40 Kasus Kekerasan Pers Terjadi di 17 Provinsi, diunduh dari http://www.rmol.co/read/2010/10/17/6719/40-Kasus-Kekerasan-PersTerjadi-Di-17-Provinsi-, pada 25 Juli 2015, 2010

Rorten, Vocab Three, diunduh dari http:/quizlet.com/18093713/vocab-three-flashcards/, pada 24 Desember 2014

Sajithra K dan Rajindra Patil, Social Media-History And Components, Journal of Business and Management, vol. 7, issue 1, 2013, http://iosrjournals.org/iosrjbm/papers/Vol7-issue1/I0716974.pdf?id=5311, diunduh tanggal 21 Juni 2016

Steve Outing, The 11 layers of Citizen Journalism. Dikutip ulang 9 Mei 2009 dari http://www.poynter.org/content/content_view.asp?id=8, 15 Juni 2005

Sugihandari, Tantangan Surat Kabar di Tengah Pusaran Teknologi, 2015, diunduh dari http://print.kompas.com/baca/2015/04/22/Tantangan-Surat-Kabar-diTengah-Pusaran-Teknologi, pada 05 Juni 2015

Supriyadi, Penerapan Hukum Pidana Dalam Perkara Pencemaran Nama Baik, dalam Mimbar Hukum Vol. 22, No. 1, Februari 2010, 2010, diunduh dari http://mimbar.hukum.ugm.ac.id/index.php/jmh/article/viewFile/307/162, pada 26 Desember 2014

Tejo Nagasakti, Sanksi Pidana Halangi Tugas dan Pentingnya Jurnalis Taati Kode Etik Jurnalistik, www.beritaekspres.com, diunduh 25 April 2016

Tujuh "Catatan Merah" AJI Jakarta di Hari Kebebasan Pers, diunduh dari http://www.ajijakarta.org/2015/05/03/tujuh-catatan-merah-aji-jakarta-dihari-kebebasan-pers-sedunia/, pada 20 Juli 2015

Twitter.com, Company Fact, diunduh dari https://about.twitter.com/company, pada tanggal 23 Juni 2016

V.A. Panggabean, Malaysia Kekang Kebebasan Pers, 2013, diunduh dari http://www.merdeka.com/dunia/malaysia-kekang-kebebasan-pers.html, pada 15 Agustus 2013

Victor Lipman, The World's Most Active Twitter City? You Won't Guess It, 2012, dalamhttp:/www.forbes.com/sites/victorlipman/2012/12/30/the-worldsmost-active-twitter-city-you-wont-guess-it/, diakses pada 17 Maret 2015 
W. Judarwanto, Langkanya Idealisme Dalam Informasi, diunduh dari http://media.kompasiana.com/mainstream-media/2011/01/25/langkanyaidealisme-dalam-informasi/, Diakses pada tanggal 25 January 2011

Willy Widianto, Putusan Pidana Prita Bukan Bebas Murni, 2011, diunduh dari: http://www.tribunnews.com/nasional/2011/07/18/putusan-pidana-pritabukan-bebas-murni, pada 27 September 2015

www.legalitas.org, 6 Januari 2014

Yohanes Paskalis, Gandeng Dewan Pers, Menkominfo Evaluasi Situs Berita Online, dalam www.tempo.co.id, diakses 4 Januari 2017 